DOI: $10.7242 / 2658-705 X / 2019.2 .5$

УДК 631.3

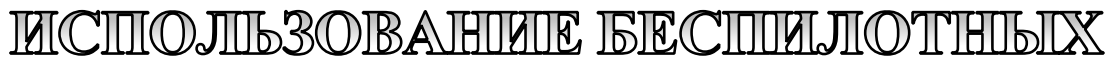

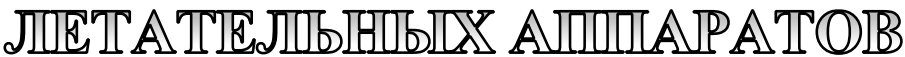

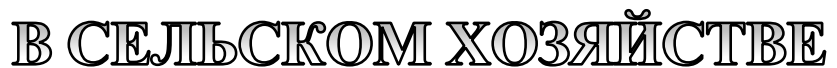

Ю.Н. Зубарев, Пермский государственный аграрно-технологический университет им. академика Д.Н. Прянишникова

Д.С. Фомин, Пермский государственный аграрно-технологический университет им. академика Д.Н. Прянишникова;

Пермский научно-исследовательский институт сельского хозяйства

А.Н. Чащин, Пермский государственный аграрно-технологический университет им. академика Д.Н. Прянишникова

М.В. Заболотнова, Пермский государственный аграрно-технологический университет им. академика Д.Н. Прянишникова

Представлен материал по использованию беспилотных летательных аппаратов (БПЛА) в сельском хозяйстве. Ежегодно возрастающая численность населения планеты привела к проникновению высоких технологий в сельское хозяйство и созданию точного земледелия. Одним из направлений точного земледелия является использование БПЛА, которые могут применяться для решения следующих задач: инвентаризация сельхозугодий, создание электронных карт полей, оценка объема работ и контроль их выполнения, оперативный мониторинг состояния посевов, оценка всхожести сельскохозяйственных культур, охрана сельхозугодий, обработка посевов пестицидами для борьбы с вредными объектами. Отмечено, что в ближайшее время БПЛА будут активно проникать во все сореры жизнедеятельности человека, в том числе и в сельское хозяйство, значительно увеличивая производительность труда на фоне снижения издержек производства.

Ключевые слова: точное земледелие, «дроны», квадрокоптеры, БПЛА, сельское хозяйство.

Возрастающая численность населения Земли за последнее десятилетие создаёт ситуацию дефицита производимой сельскохозяйственной продукции. По оценке ФАО, к 2050 году население на планете достигнет - 9,6 млрд. человек, то есть станет на треть больше, чем сегодня. Следовательно, сельскохозяйственным предприятиям нужно производить в два раза больше сельскохозяйственной продукции. Вот почему развитие сельскохозяйственной отрасли неизбежно, что является непременным итогом рыночной экономики, приводящей к усилению конкуренции по качеству, цене и независимости урожая от погоды и вредителей, затратам на содержание техники и персонала и т.д. [6].

Современный агропромышленный комплекс работает по тем же принципам, что и любой бизнес, при постоянном стремлении снижать себестоимость единицы продукции с повышением производительности в расчёте на единицу затратных ресурсов. На протяжении всего $\mathrm{XX}$ века достигать этих целей позволял классический инструментарий: энергоём- 
кие сельскохозяйственные машины, высокопродуктивные сорта сельскохозяйственных культур, эффективные методы ухода (удобрения, регуляторы роста) и оптимальные агротехнические приемы. Сегодня эти инструменты по-прежнему актуальны, но их потенциал практически достиг предела, возможного при современном уровне агротехнологий. В настоящее время появились новые инструменты, в частности спутниковые и компьютерные технологии, ставшие общедоступными. Их освоение и внедрение в сельское хозяйство привело к созданию точного земледелия [4, 7].

Одним из перспективных направлений в точном земледелии является использование беспилотных летательных аппаратов (БПЛА) - «дронов», в обиходе - «беспилотников». Беспилотный летательный аппарат (БПЛА) - это летательный аппарат без экипажа на борту, способный обладать разной степенью автономности - от управляемого дистанционно до полностью автоматического режима, а также различаться по конструкции и назначению.

«Дроны» используются в коммерческих целях с начала 1980-х годов. В последние годы возможности практического применения дронов начинают расширяться $[1,3]$.

Так, в 2016 году оценка мирового рынка беспилотных летательных аппаратов составила 7,3 млрд. долларов, но прогнозируется, что к 2020 году он вырастет до 9,5 млрд. долларов. В настоящее время Россия занимает небольшую долю в продажах «дронов», около 2\%, но имеет высокий потенциал для дальнейшего роста. Специфика российского рынка БПЛА заключается в преобладании производителей военных «дронов» и практически полном отсутствии производителей потребительских и коммерческих «дронов». При этом преобладающая часть производителей военных БПЛА имеет в своем портфеле либо уже устаревшие технически модели, либо только опытные современные образцы, которые демонстрируются на выставках, но не поступают в массовое производство, и, несмотря на значительные бюджетные влива- ния со стороны государства, продукция российских компаний сейчас не выдерживает конкуренции с западными образцами.

Использование БПЛА в сельском хозяйстве может совершить настоящий прорыв, значительно снизив производственные затраты. Использование беспилотных летающих аппаратов в производстве продукции растениеводства широко практикуется в США, Китае, Японии, Бразилии и многих европейских странах. По данным организации AUVSI, в отчете под названием «The Economic Impact of Unmanned Systems Integration in the United States» [13], применения БПЛА в сельском хозяйстве будут преобладать над всеми остальными применениями («dwarf all others») и к 2025 году около 80\% рынка беспилотных машин («дронов») будет занято в сельском хозяйстве США.

Актуально использование беспилотных летательных средств и для сельского хозяйства России. Стране с обширной территорией и большими посевными площадями, мониторинг сельхозугодий зачастую является трудной задачей. При государственной поддержке Россия к 2035 году может занять от 15-20\% (базовый сценарий) до 20-25\% (оптимистический сценарий) мирового рынка в сельском хозяйстве.

В денежном эквиваленте объём рынка по оказанию услуг на основе БАС в аграрном секторе, занимаемый российскими компаниями, - 240 млрд. рублей, а продажа БВС достигнет дополнительно 27 млрд. рублей.

Применение БПЛА в сельском хозяйстве (табл. 1) имеет огромный потенциал, и с каждым годом интерес к их использованию растет. Применение беспилотных летательных аппаратов в сельском хозяйстве является инновацией для России, в первую очередь, при реализации задач точного земледелия [8]. «Беспилотники» оснащаются разнообразными датчиками, в том числе мультиспектральными камерами, высокая четкость изображения которых позволяет точно определять проблемные участки поля, системами спутниковой навигации, малогабаритными 
Целевые возможности применения беспилотных летательных аппаратов в сельском хозяйстве $[10,11]$

\begin{tabular}{|c|c|}
\hline В земледелии & В зоотехнии и ветеринарии \\
\hline $\begin{array}{l}\text { • инвентаризация сельхозугодий; } \\
\text { • создания электронных карт полей; } \\
\text { • оценка объема работ и контроль их выполнения; } \\
\text { • оперативный мониторинг состояния посевов; } \\
\text { • оценка всхожести сельскохозяйственных культур; } \\
\text { • охрана сельхозугодий; } \\
\text { • обработка посевов пестицидами для борьбы с } \\
\text { вредными объектами. Сканируя посевы, могут } \\
\text { распылять необходимое количество жидкости, } \\
\text { корректируя высоту полета и объем жидкости в } \\
\text { реальном времени и обеспечивая равномерное } \\
\text { покрытие всей площади. }\end{array}$ & $\begin{array}{l}\text { • контроль здоровья животных; } \\
\text { • мониторинг мест выпаса; } \\
\text { • ветеринарная помощь (с помощью БПЛА можно } \\
\text { дистанционно ввести успокоительное, вакцину, } \\
\text { антибиотик или глистогонное средство); } \\
\text { • судебная экспертиза (оценка ущерба посевов, } \\
\text { причиненного животным); } \\
\text { • безопасность и охрана животных на выпасе; } \\
\text { • сбор скота в стадо; } \\
\text { • мониторинг питания и водного баланса животных. }\end{array}$ \\
\hline
\end{tabular}

бортовыми компьютерами и оборудованием для внесения химикатов и т.д.

Следует заметить, что на сегодняшний день беспилотные летательные аппараты в нашей стране не так популярны, данное направление находится на начальном уровне. За последние несколько лет разработано множество различных проектов применения сельскохозяйственных «дронов», но более $90 \%$ из них до сих пор не воплощены в реальность [12]. Причин этого несколько (табл. 2):

Во-первых, слабым звеном «дронов» остаётся управление, которое требует определенного обучения. Так, при управлении летательным аппаратами весом в несколько килограмов, способными совершать полёт на высоте в несколько сотен метров, недостаток навыков управления пилотов-операторов, представляет опасность для окружающих людей, имущества и даже для полетов «традиционных» летательных аппаратов.

Во-вторых, безопасность полетов касательно вопросов неприкосновенности личной жизни и тонкостей страхования. Однако главной проблемой для сельского хозяйства является тип и качество получаемых данных.

В-третьих, важным блоком вопросов остается влияние погодных факторов на управление беспилотниками.

В-четвертых, серьезной проблемой для сектора остается и вопрос цены беспилотного летательного аппарата, все зависит от технологического уровня ком- пьютера беспилотной системы.

В-пятых, полномасштабному внедрению дронов в сельское хозяйство препятствует законодательство.

Так, в соответствии с Федеральном законом от 03.07.2016 №291-Ф3 «О внесении изменений в воздушный кодекс Российской Федерации» [14] беспилотные авиационные системы и их элементы подлежат обязательной сертификация на основе федеральных авиационных правил. Обязательная сертификация завершается выдачей сертификата, если в ходе проведения сертификации установлено, что беспилотные авиационные системы и (или) их элементы соответствуют требованиям к летной годности и к охране окружающей среды.

Иными словами, все владельцы БПЛА обязаны регистрировать свои аппараты весом от 0,25 до 30 кг, ввезенные или произведенные в РФ. Формально под это определение попадают не только промышленно изготовленные дроны, продукция кружков авиамоделирования, но и детские радиоуправляемые игрушки, и даже воздушные змеи. Ссылаясь на федеральный закон, управлять дроном сможет только внешний пилот с правами [5]. В таком развитии событий необходимо обеспечить грамотное обучение специалистов-аграриев, направленное на оперативную работу с информацией и принятие эффективных управленческих решений. Для нормального развития отрасли нужны также правила, разрешающие полеты дронов в явочном 


\section{SWOT - анализ «Использование «беспилотников»}

в сельском хозяйстве Российской Федерации»

\begin{tabular}{|c|c|}
\hline Сильные стороны & Слабые стороны \\
\hline $\begin{array}{l}\text { - Оперативность получения снимков. БПЛА позволяют } \\
\text { вести съемку даже в условиях облачности, что } \\
\text { недоступно спутникам и затрудняет использование } \\
\text { авиации. } \\
\text { • Возможность применения в зонах чрезвычайных } \\
\text { ситуаций без риска для жизни и здоровья пилотов. } \\
\text { - БПЛА могут обладать разной степенью. } \\
\text { автономности - от управляемых дистанционно до } \\
\text { полностью автоматических. } \\
\text { • Доступность и простота использования. }\end{array}$ & $\begin{array}{l}\text { - Ограниченное время полёта в связи с малой } \\
\text { ёмкостью аккумулятора. } \\
\text { - Ограниченный подъемный вес (к примеру, } \\
\text { квадрокоптер для сельского хозяйства DJI Agras } \\
\text { МG-1, основной фуннццей которого является } \\
\text { опрыскивание полей, может поднимать до } 10 \text { кг } \\
\text { жидкости для орошения). } \\
\text { - Плохо управляемы в плохих погодных условиях } \\
\text { (сильный ветер, дождь). } \\
\text { - Необходимо соответствующее программное } \\
\text { обеспечение, так как количество систем мобильного } \\
\text { мониторинга с использованием БПЛА является } \\
\text { крайне ограниченным и в основном находится на } \\
\text { стадии проектов. }\end{array}$ \\
\hline Возможности & Угрозы \\
\hline $\begin{array}{l}\text { - Обследование и подкормка вегетирующих посевов, } \\
\text { так как во многих случаях такие технологические } \\
\text { операции затруднены при высоком стеблестое } \\
\text { некоторых культур и невозможности по этой причине } \\
\text { использования для этих целей наземных агрегатов. } \\
\text { • Опрыскивание посевов химическими препаратами } \\
\text { для борьбы с вредителями и болезнями. } \\
\text { • Создание электронных карт полей. } \\
\text { • Инвентаризация сельхозугодий. } \\
\text { • Оценка и контроль объема выполнения работ. } \\
\text { • Отслеживание нормализованного вегетационного } \\
\text { индекса с целью эффективного внесения удобрений. } \\
\text { • В динамике контролирование состояния посевов } \\
\text { сельскохозяйственных культур и оперативное } \\
\text { принятие управленческих решений на } \\
\text { изменяющуюся ситуацию. }\end{array}$ & $\begin{array}{l}\text { - Согласно федеральному закону №291-Ф3 от } \\
\text { 03.07.2016 «О внесении изменений в воздушный } \\
\text { кодекс Российской Федерации» управлять дроном } \\
\text { может только внешний пилот с правами. } \\
\text { - Необходимо пройти регистрацию БПЛА. } \\
\text { - Недостаток специалистов. } \\
\text { - Перехват управления БПЛА, угон. } \\
\text { - Недостаточное финансовое обеспечение } \\
\text { сельскохозяйственного производства. } \\
\text { - Импортное производство БПЛА } \\
\text { и соответствующего программного обеспечения. }\end{array}$ \\
\hline
\end{tabular}

порядке, а не в разрешительном, ограничив их лишь определенной высотой, определив запретные зоны и т.д.

Несмотря на трудности, которые испытывает индустрия беспилотной авиации сейчас, в ближайшем будущем в сфере беспилотных летательных аппаратов ожидается прорыв: дроны станут доступны практически каждому, будут обладать большим временем полета, камерами с высоким разрешением, различными специализированными устройствами, системами безопасности полета и помощью в управлении [12].

Таким образом, благодаря развитию технологий, БПЛА будут активно проникать во все сферы жизнедеятельности человека, в том числе и сельское хозяйство, значительно увеличивая производительность труда и снижая издержки производства.

\section{Библиографический список}

1. Бауэрс П. Летательные аппараты нетрадиционных схем. - М.: Мир, 2016. - 320 с. (С. 130-131).

2. Василин Н.Я. Беспилотные летательные аппараты. - Минск: Попурри, 2017. - 272 с. (С. 5-7, 98-105).

3. Обработка почвы как фактор регулирования почвенного плодородия: монография / A.Ф. Bumep, В.И. Турусов, В.М. Гармашов [и др.] - М.: НИЦ ИНФРА-М, 2014. - 173 с.

4. Кучкарова Д.Ф., Хаитов Б.У. Современные системы ведения сельского хозяйства // Молодой ученый. - 2015. - №12. - С. 222-223.

5. Лященко Ю.В. Правовой аспект использования беспилотных аппаратов в России // Актуальные проблемы авиации и космонавтики. - 2016. - №12. URL: https://cyberleninka.ru/article/n/pravovoyaspekt-ispolzovaniya-bespilotnyh-apparatov-v-rossii (дата обращения: 28.01.2019). 
6. Семыкин В.А., Пигорев И.Я. Научное обеспечение инновационного развития сельского хозяйства Курской области // Региональные проблемы повышения эффективности агропромышленного комплекса: материалы всерос. науч.-практ. конф. - 2007. - С. 3-10.

7. Труфляк Е.В. Основные элементы системы точного земледелия. - Краснодар: КубГАУ, 2016. -39 с.

8. Хорт Д.О., Личман Г.И., Филиппов Р.А., Беленков А.И. Применение беспилотных летательных аппаратов (дронов) в точном земледелии//Фермер. Поволжье. -2016. -№ 7. -С. 34-37.

9. Можно ли использовать беспилотники в животноводстве? // Форум робототехники RoboTrends. - M., 2016. [Электронный ресурс] URL: http://robotrends.ru/pub/1617/mozhno-li-ispolzovat-bespilotniki-vzhivotnovodstve-i-veterinarii-bezuslovno (дата обращения 28.01.2019).

10. Как дроны преобразовывают сельское хозяйство.// Независимое издание RUSBASE. - M., 2016. [Электронный ресурc] URL: http://rb.ru/list/agriculture-drones/ (дата обращения 28.01.2019).

11. Будущее животноводства за беспилотными летательными аппаратами. // Информационное агентство Milknews.ru. - M., 2016. [Электронный pecypc] URL: http://milknews.ru/index/Technology/Technology_952.html (дата обращения 28.01.2019).

12. Что мешает беспилотникам развиваться? // Независимое издание RUSBASE. - M., 2015. [Электронный ресурс] URL: https://rb.ru/opinion/drones-challenge/ (дата обращения 28.01.2019).

13. The Economic Impact of Unmanned Systems Integration in the United States. [Электронный pecypc] URL: https://higherlogicdownload.s3.amazonaws.com/AUVSI/958c920a-7f9b-4ad2-9807-f9a4e95d1 ef1/ UploadedImages/New_Economic\%20Report\%20 2013\%20Full.pdf (дата обращения 28.01.2019).

14. Федеральный закон от 3 июля 2016 г. № 291-Ф3 «О внесении изменений в Воздушный кодекс Российской Федерации» [Электронный http://www.garant.ru/hotlaw/federal/775843/\#ixzz5dtiboWRA (дата обращения 28.01.2019).

\title{
USE OF UNCLEANED AIRCRAFT IN AGRICULTURE
}

\author{
Yu.N. Zubarev ${ }^{1}$, D.S. Fomin ${ }^{1,2}$, A.N. Chashchin ${ }^{1}$, M.V. Zabolotnova ${ }^{1}$ \\ ${ }^{I}$ Perm State Agro-Technological University named after Academician D.N. Pryanishnikov \\ ${ }^{2}$ Perm Scientific Research Institute of Agriculture
}

The article presents material on the use of unmanned aerial vehicles (UAVs) in agriculture. The annual growing population of the planet has led to the penetration of high technologies in agriculture and the creation of precision farming. One of the areas of precision farming is the use of UAVs, which can be used to solve the following tasks: inventory of farmlands, creating electronic field maps, estimating the scope of work and monitoring their implementation, operative monitoring of the condition of crops, evaluating the germination of crops, protecting agricultural land for combat harmful objects. It was noted that in the near future, UAVs will actively penetrate into all spheres of human activity, including agriculture, significantly increasing labor productivity against the background of lower production costs.

Keywords: precision farming, drones, quadrocopters, UAVs, agriculture.

\section{Сведения об авторах}

Зубарев Юрий Николаевич, доктор сельскохозяйственных наук, зав. кафедрой общего земледелия и защиты растений, Пермский государственный аграрно-технологический университет им. академика Д.Н. Прянишникова (Пермский ГАТУ), 614990, г. Пермь, ул. Петропавловская, 23; e-mail: zemledel@pgsha.ru

Фомин Денис Станиславович, кандидат сельскохозяйственных наук, старший научный сотрудник Пермский научно-исследовательский институт сельского хозяйства - филиал Пермского федерального исследовательского центра УрО РАН (Пермский НИИСХ), 614532, Пермский край, Пермский район, с. Лобаново, ул. Культуры, 12; доцент кафедры общего земледелия и защиты растений, Пермский ГАТУ; e-mail: akvilonag@mail.ru

Чащин Алексей Николаевич, кандидат биологических наук, доцент кафедры почвоведения, Пермский ГАТУ; e-mail: chascshin@mail.ru

Заболотнова Мария Валерьевна, аспирант кафедры общего земледелия и защиты растений, Пермский ГАТУ; e-mail: zemledel@pgsha.ru 